\title{
DESIGN RESEARCH ON APPLIED REALISTIC MATHEMATICS EDUCATION (RME) APPROACH IN TEACHING MATH FOR VOCATIONAL COLLEGE
}

\author{
Sri Imelda Edo \\ Politeknik Pertanian Negeri Kupang \\ Wahyuni Fanggi Tasik \\ Politeknik Pertanian Negeri Kupang
}

\begin{abstract}
Several studies documented that mathematics, as it is taught in general secondary education, is far away from what is needed for most fields of vocational practice. Some studies found that workplace mathematics demands are very different from traditional mathematics taught in classrooms. Therefore, this study aims to design a learning trajectory for teaching mathematics in vocational college, oriented on the Realistic Mathematics Education (RME) approach to improve students' understanding and motivation in learning mathematics. Design research was chosen as an appropriate method to answer the research questions and achieve the research goals. Design research methods consist of three phases, namely preliminary design, experiment, and retrospective analysis. The research result shows that the learning trajectory can improve students' understanding. Students enjoy the learning process and give a very enthusiastic response.

Keywords: math for vocational education, RME approach for adult, learning trajectory, math for marine and fisheries, set operation
\end{abstract}

Permalink: http://dx.doi.org/10.21831/jpv.v9i3.27839

Contact Sri Imelda Edo sriedo830@gmail.com

Politeknik Pertanian Negeri Kupang

Jl. Prof. Dr. Herman Johanes, Lasiana, Klp. Lima,

Kota Kupang, Nusa Tenggara Timur 85011, Indonesia 


\section{INTRODUCTION}

Mathematics is one of the core courses for all diploma-level engineering and agriculture students. Moreover, mathematics plays an important role in improving students' skills in Technical Vocational Education and Training (TVET). However, research in the Vocational Education and Training (VET) sector in Australia showed that workplace mathematics demands are very different from traditional mathematics taught in classrooms (Javed, 2008). Furthermore, Malaysian Polytechnic students' achievement in the Engineering Mathematics 2 course is still moderate and less satisfactory, because the subject of Mathematics is mostly related to calculus (Hussin et al., 2018). In the Netherlands, many mathematical issues that are taken for granted in general education are useless in vocational settings, while other aspects of mathematics turn out to be very important (van der Kooij, 2011). In addition, in China, students' poor practical capability is the main problem appearing in teaching of higher vocation colleges at present (Zhang, 2014).

In Indonesia, Rusmar (2017) says that most of the students at Politeknik Teknologi Kimia Industri (PTKI) Medan have perceived difficulties in accepting mathematics knowledge because all of the topics included are difficult to implement in their working lives. Furthermore, students in Politeknik Pertanian Negeri Kupang (or Polytechnic of Agriculture, Kupang), in Indonesia, found difficulties in doing math operation, i.e., fractions, because they have lack of mathematics concept (Edo, 2016). They tend to memorize some routine procedures given by their teacher in a prior stage of study and try to look for similar examples in the textbooks or the internet to solve mathematics problems. In some interview sections, students argue that learning mathematics means memorizing an abstract formula that does not make sense to them. They have not found a real connection about mathematics with their major of study.

The set theory lies at the foundation of mathematics. The concepts in set theory, such as functions and relations, are explicitly or implicitly used in every branch of mathematics. The basic concept of all fields of mathematics is that of a set. The learning set is important for vocational college. The rough set concept can be of some importance, primarily in some branches of artificial intelligence, such as inductive reasoning, automatic classification, pattern recognition, learning algorithm, etc. The idea of the rough set can be placed in a more general setting, leading to fruitful further research and application in classification theory, cluster analysis, and measurement area (Hodgson, 1996) related to agriculture advance.

However, teachers teach set operations using symbolic forms or something abstract. They just give some examples of various types of the set with number or alphabet asset elements that do not make sense for students. Most teachers are affected by the traditional teaching approach. They tend to adopt traditional teaching modes and impart a great deal of content with high difficulty to students by a large-capacity explanation (Zhang, 2014). An important finding for the designers of the WISKUNDE program in the Netherland is the fact that mathematics, as it is taught in general secondary education, is far away from what is needed for most fields of vocational practice (van der Kooij \& Strasser, 2004). Most of the vocational trainers use the mathematical routines, merely algebraic algorithms they learned themselves a long time ago.

RME is considered an auspicious approach to improve mathematics teaching and make it more relevant for vocational education. Within a realistic approach, mathematics is viewed as an activity, away from working (de Lange, 1987, 1996; Fauzan et al., 2002; Freudenthal, 1973; Gravemeijer, 1994; Treffers, 1987). RME approach starts from a realistic context, which allows students to reinvent mathematical concepts under the guidance of the teacher. Its characteristics are proper to vocational college curriculum that is more focused on technical skills than mastering theory.

Furthermore, students should be given the context which is relevant to the vocational education field, rich in math concept, interesting, and academical. It can be one of the solutions to improve students' habits in academic reading and their attitude toward mathematics. The context provides sufficient scientific information and mathematics concepts altogether. Therefore, students can deeply understand about mathematics' utilities to their field of study. One of the vocational colleges in 
Indonesia is Polytechnics of AgricultureKupang (or Politeknik Pertanian Negeri Kupang), located in East Nusa Tenggara province. The college has five departments; one of them is marine and fisheries. One popular icon of East Nusa Tenggara province is a marine national park (MNP) called Savu Sea MNP.

Savu Sea MNP is one of the important habitats and migratory corridors for cetaceans and turtles, a vital nursery area for fish, and a refuge for coral reefs. It has unique oceanographic features, including deep trenches, strong currents, and areas of upwelling. Therefore, Savu Sea MNP is an essential habitat for marine biodiversity in the world. However, these resources are being threatened by unsustainable and destructive fishing pressure and increasing coastal development. Thus, students in marine and fisheries major should have enough knowledge about Savu Sea MNP's biodiversities. Set knowledge and its representation skill can be the basis for students to classify the species of mammals and turtles according to their distribution area. Therefore, conservancy effort, i.e., reducing coastal flood risk, can more focus on their habitat. Mapping their species area is one of the solutions to protect them from human threats. The government, as policymakers, would give more attention to protect the related area. Thus, Savu Sea MNP, especially the marine mammals' species and sea turtles distributed habitat, are potential context which can be used as a starting point in teaching and learning for students in fisheries and marine department.

Finally, it is a model of a mathematics learning trajectory in a set topic designed oriented on the RME approach for vocational education students. The research questions of this study are (1) how can the learning trajectory using RME approach construct and improve students understanding, (2) how can learning trajectory using RME approach improve students' motivation in learning mathematics, and (3) what is the perception of student with respect to the RME approach and its context?

A set is a collection of well-defined objects. The objects of a set are called elements or members of the set. The main property of a set is that it is well defined. It means that given any object, it must be clear whether that object is a member (element) of the set or not. Generally, as presented in Table 1, sets are named with the capital letters A, B, C, etc. The elements of a set are denoted by the small letters a, b, c, etc. When two or more sets are combined to form another set under some given conditions, then operations on sets are carried out (Math-Only-Math.com, n.d.).

In RME, the real context is used as a starting point for the development of mathematical concepts and ideas. Blum and Niss (1989) state that context is the rest of the world outside mathematics, i.e., school or university subjects or disciplines different from mathematics, or everyday life and the world around us (Zulkardi, 2002a). However, we have to be careful because the real world here is the world that is concrete for students. A concept may be concrete for a mathematician but is not necessarily concrete for children. In addition, de Lange (1996) defines a concrete real-world as "the world that comes across to children and students through mathematics in applications." It is a way to understand students' mathematical learning as it occurs in the real situation. There are five characteristics (tenets) of RME (de Lange, 1987; Gravemeijer, 1994) such as (1) the use of contexts in phenomenological exploration, (2) the use of models, (3) the use of students' creations and contributions, (4) interactivity; and (5) the intertwining of various mathematics strands or units.

Table 1. Laws on Set Operation

\begin{tabular}{lll}
\hline $\begin{array}{l}\text { Identity laws: } \\
A \cup \emptyset=A\end{array}$ & $\begin{array}{l}\text { Commutative laws: } \\
A \cup B=B \cup A\end{array}$ & $\begin{array}{l}\text { De Morgan's laws: } \\
(A \cup B)^{\prime}=A^{\prime} \cap B^{\prime} . \\
(A \cap B)^{\prime}=A^{\prime} \cup B^{\prime}\end{array}$ \\
\hline $\begin{array}{l}\text { Domination laws: } \\
A \cup U=\mathrm{U}=\mathrm{B}=\mathrm{B} \cap \mathrm{A}\end{array}$ & $\begin{array}{l}\text { Associative laws: } \\
\mathrm{A} \cup(\mathrm{B} \cup \mathrm{C})=(\mathrm{A} \cup \mathrm{B}) \mathrm{UC}\end{array}$ \\
$\mathrm{A} \cap \varnothing=\varnothing$ & $\mathrm{A} \cap(\mathrm{B} \cap \mathrm{C})=(\mathrm{A} \cap \mathrm{B}) \cap \mathrm{C}$ & \\
\hline $\begin{array}{l}\text { Idempotent laws: } \\
\mathrm{A} \cup \mathrm{A}=\mathrm{A}\end{array}$ & $\begin{array}{l}\text { Distributive laws: } \\
\mathrm{A} \cup(\mathrm{B} \cap \mathrm{C})=(\mathrm{A} \cup \mathrm{B}) \cap(\mathrm{A} \cup \mathrm{C})\end{array}$ \\
$\mathrm{A} \cap \mathrm{A}=\mathrm{A}$ & $\mathrm{A} \cap(\mathrm{B} \cup \mathrm{C})=(\mathrm{A} \cap \mathrm{B}) \cup(\mathrm{A} \cap \mathrm{C})$ & \\
\hline
\end{tabular}


In Realistic Mathematics Education (or RME), a context plays an important role. It distinguishes RME from other mathematics teaching approaches, such as the mechanistic and structural approaches. By employing contextual problems, the instruction is directed to the processor reinvention of mathematical concepts through both horizontal and vertical mathematics. The use of real-life problems related to students' field of study as the starting point in mathematics teaching will engage college students in meaningful mathematical activities. The problematic natures of RME contextual problems can also trigger interactivity among students. Students gain mathematics knowledge by comparing their answers to others', asking questions, justifying, and also drawing conclusions (Zulkardi, 2002b).

The term context in RME refers primarily to the described situation in which the problem is placed, and from what students can produce mathematical activity as well as practice and apply their mathematical knowledge (Gravemeijer, 1981). In RME, the context can also be mathematical, as long as the students see it as real. Edo et al. (2013) state that there are four categories of context in mathematics literacy, i.e., personal, occupational, societal, and scientific.

Before taking the class, a teacher has to prepare some teaching material using a relevant teaching approach. In order to reach learning outcomes and improve students' achievements, the teacher has to plan instructional activities and hypothesize the learning process. In designing an instructional activity, a teacher should anticipate the collective mathematical development of the classroom community, and students' reaction to each stage of the learning. It is in line with Simon (1995) who states that:

\section{"A hypothetical learning trajectory consists of learning goals for students, planned instruct-tional activities, and a hypothesized learning process in which the teacher anticipates the collective mathematical development of the classroom community and how students' understanding might evolve as they participate in the learning activities of the classroom community" (Wijaya, 2008).}

As mentioned by Huffard et al. (2012), the Savu Sea and surrounding areas in the East Nusa Tenggara province is an important area for marine mammals in Indonesia. The area provides critical habitat for these species, such as migratory corridors, feeding, and also nursery areas. The area supports a broader diversity of 22 species of marine mammal, including vulnerable and endangered species, such as Blue Whale and Sperm Whale. Ombai Strait and the Timor Sea are also contained within the IMMA boundary and have been identified as a migratory corridor for the Pygmy Blue Whale. This corridor in the Savu Sea connects the migratory line between north-west Australia and Banda-Seram Seas. All marine mammals in Indonesia have been fully protected since 1999, and this area was declared as the Savu Sea Marine National Park (MNP), whose roles, one of which is protecting marine mammals. However, traditional whaling communities are still identified as a threat to the cetacean population within the region, as well as illegal, unreported and unregulated fishing, increasing marine traffic, and oil-gas exploration.

\section{RESEARCH METHOD}

For this purpose, design research was chosen as an appropriate means for answering the research questions and achieving the research goals. In this research, a set of experience-based activities was designed as a flexible approach to understand and improve educational practices of Set Theory for vocational college students in the marine and fisheries department. The phases in this design research are preliminary design, experiment, and retrospective analysis. The phase of the research method is summarized in Figure 1.

This study was conducted in the Aquaculture study program, Marine and Fisheries Department, Polytechnics of Agriculture in Kupang. Eleven students were involved in pilot experiment stage, and thirty five students in experiment stage. In addition, an expert in mathematics education, an expert in the marine conservancy, two colleagues, and a model lecturer, were participated to review the hypothetical learning trajectory (HLT) and learning material. Data were collected through (1) video and (2) written data. The videotaping during the teaching experiments was recorded by two cameras; one camera as a static camera to record the whole class activities and the other camera as a dynamic camera to record the activities in some groups of students. In addi- 
tion, the written data included students' work during the teaching experiment, observation sheets, the results of assessments, including the final assessment, and some notes gathered during the teaching experiment.

Data were analyzed retrospectively, in which hypothetical learning trajectory (HLT) was compared with students' actual learning to investigate and to explain how students acquire the basic concepts of set and set operation that was elicited by marine mammals and reptile species' context. The main data needed to answer the first research question were the videotaping of the students' activities and the class discussion. The reasoning of why students given different answers was investigated from students' arguments in the class discussion. How students found the relation of sets and their properties were needed as the additional data to answer research questions. Classroom norms were analyzed based on videotaping and field notes to answer the second and third questions.

Reliability was conducted in two ways, namely: (1) data triangulation, in which the combination of the videotaping, the students' works, and some notes from either teacher or observer were chosen to check the reliability of interpretations based on one video clip or one field note, and (2) cross interpretation, in which, to reduce the subjectivity of the researchers' point of view, the parts of the data (especially the video data) were also crossinterpreted with colleagues. The methods of validity used in the data analysis are (1) HLT, as a guideline and a point of reference in answering research questions, aimed at connecting and evaluating the initial conjectures to the gathered data and prevented systematic bias, and (2) trackability of the conclusions. Hypothetical learning trajectory (HLT) is a means to support validity; the HLT was used in retrospective analysis. Meanwhile, in the trackability of the conclusions, the educational process was documented by video recordings, field notes, students'written answers. Those data were used to describe the situation and the findings in detail to give sufficient information for our reasoning. This information enables the readers to reconstruct the reasoning and to trace the arguments that underpin the conclusions.

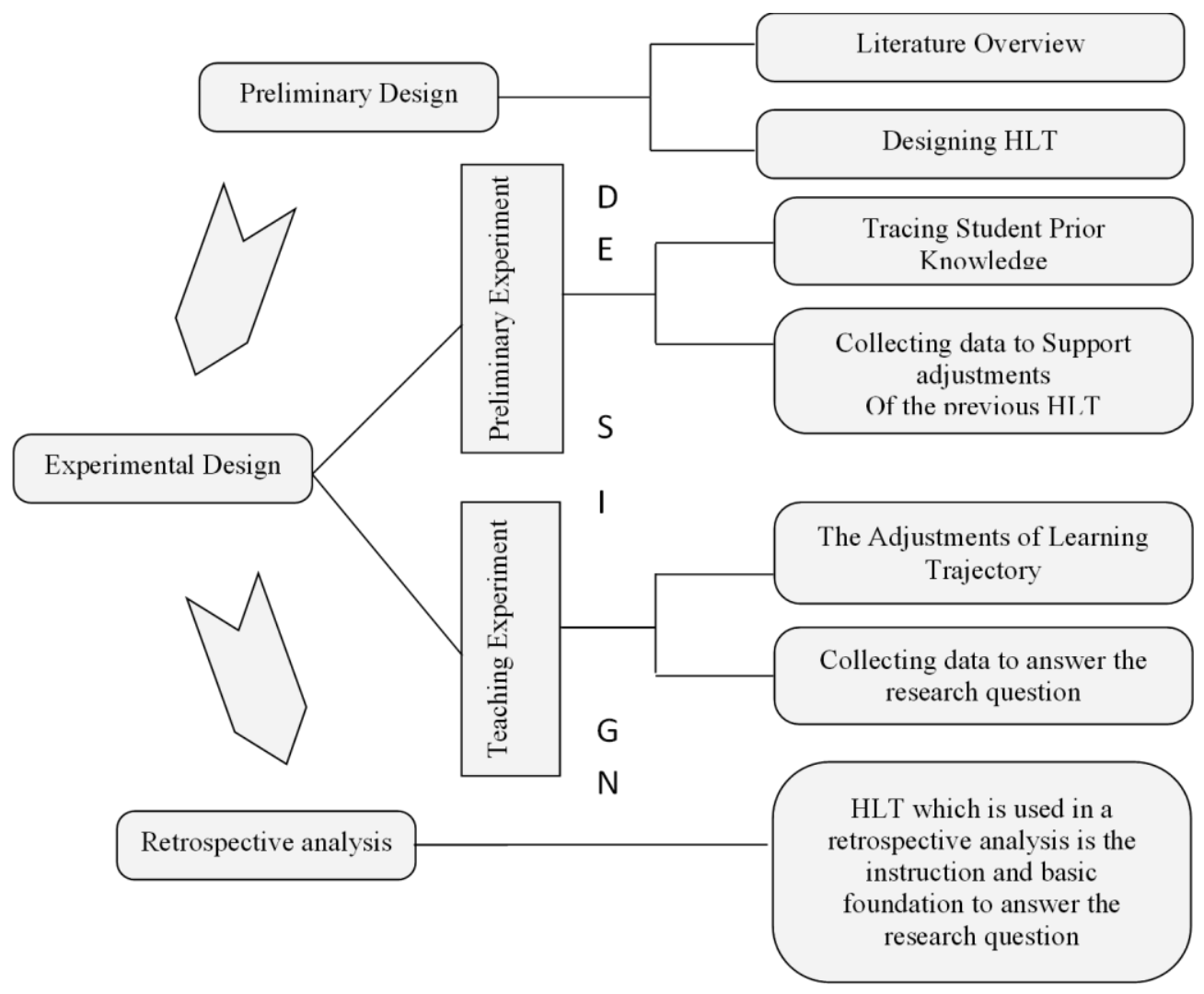

Figure 1. Design Research's Phase (Prahmana et al., 2012) 


\section{RESULTS AND DISCUSSION}

In order to facilitate students' understanding of the set concept, set types, set representation, set relation refers to the set's laws, the researches designed two HLT. The first HLT covered set concept, set types, and set representation, while the second one was about laws on the set operation. The first HLT used the context of marine mammals in Savu Sea MNP, and the other HLT used the sea turtle species distribution in Savu Sea MNP.

\section{Preliminary Design}

In the preliminary design, initial ideas were implemented. They were inspired by studying literature about set theory, set operation, and laws on the set operation, the biodiversity in Savu Sea MNP, RME, and design research, as the bases for formulating initial conjectures in learning set theory. The HLT was designed based on the RME approach, which uses context as a starting point in teaching and learning. The first HLT was designed using Marine Mammals Species in Savu Sea MNP as the context, while the second distribution of marine mammal species in the Savu Sea was documented by several studies. The context is presented in Figure 2.

Moreover, a sequence of instructional activities containing conjectures of students' thinking was developed. The conjectured hypothetical learning trajectory was dynamic and could be adjusted to students' actual learning during the teaching experiments (see Table 2 and Table 3).

However, in the second HLT, students were given the text about turtle species in the Savu Sea MNP as the context. The context is starting point in the teaching and learning based on RME approach (see Figure 3).

\section{MARINE MAMMALS IN SAVU SEA MNP}

Savu Sea NMCA covers ranges of species diversities and habitats. Its region is main migratory corridors and habitats for 14 whale's species, 7 dolphin's species, and 1 dugong's species (Savu Sea Management Plan, 2013, p.42). Each picture of marine mammal's species shown below

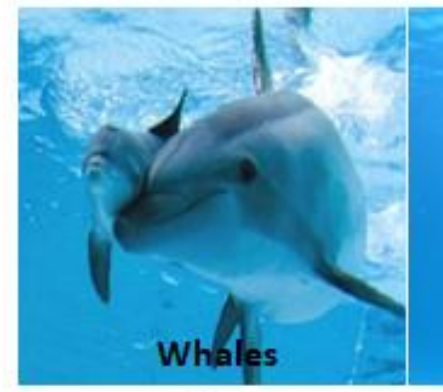

source:bttps://www.referensibeb as.com/2016/09

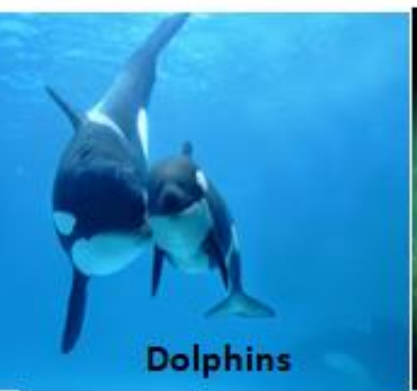

Source:httrps://www. referen sibebas.com/2016/09

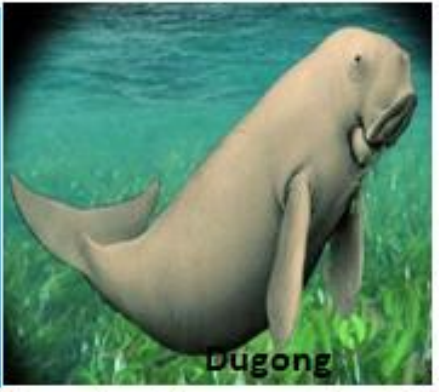

Source. $h$ ttps: //www. amazine.co/2210 0/9-informasi-fakta-menarik-tentangdugong-duyung/

Sawu Sea region is known as a migration area for marine mammals. Recent surveys by Kahn (2009) and Mapping of Sayu Sea MNP's Participatory (2010), in the savu sea MNP documented a high abundance of cetacean, and identified significant habitats and migratory corridors for 14 whale's species (Sperm whale, Dwarf sperm whale, Pygmy sperm whale, Short finned whale pilot, Orca, False killer whale, Pygmy killer whale, Melon headed whale, Beaked whale, Cuvier's beaked whale, Bryde's whale, Pygmy Bryde's whale, Blue whale, Humpback whale), 7 dolphin's species (Spinner dholpin, Pan-tropical spotted dolphin, Rough-toothed dolphin, Risso's dolphin, Bottlenose dolphin, Fraser's dolphin, Indo-Pacific bottlenose dolphin), and 1 dugong's species (Sayu Sea Management Plan, 2013, p.42). These crossings are important in terms of efforts to manage the region itself, which means that in its management, the area that is a part of the crossing corridor must be a main concern as well.

Figure 2. Context about Marine Mammals Species in Savu Sea MNP 
Table 2. Learning Trajectory on Set Concept

\begin{tabular}{lll}
\hline \multicolumn{1}{c}{ Mathematics Goal } & \multicolumn{1}{c}{ Activity } & \multicolumn{1}{c}{ Description } \\
\hline $\begin{array}{l}\text { 1. Students inventing the set } \\
\text { concept }\end{array}$ & $\begin{array}{l}\text { - Read the context of Mammals } \\
\text { Species found in Savu Sea } \\
\text { MNP according to several prior } \\
\text { studies. }\end{array}$ & $\begin{array}{l}\text { Students have difference answer (some of them } \\
\text { choose species of Whales as the clever species, } \\
\text { while some students choose dolphin species and } \\
\text { dugong species as the clever species. Few of them }\end{array}$ \\
& $\begin{array}{ll}\text { - Students list the members of } \\
\text { clever species of mammals that no clever species of mammals or all of } \\
\text { found in Savu Sea MNP. }\end{array}$ & $\begin{array}{l}\text { the mammal species are the clever species, so } \\
\text { they fell hard to list its members }\end{array}$ \\
& $\begin{array}{l}\text { Their difference answer guided them to find that } \\
\text { set is the collection of well define object. }\end{array}$
\end{tabular}

2. Students distinguish undefined object with an empty set

3. Represent sets and set relation

4. Represent sets and set relation

5. Venn Diagram
- Students list the species of seal found in Savu Sea MNP work sheet to decide whether the collection of seal species in Savu Sea MNP is a set or not?
- Students solve the problem on

- Some students list the species of Seal and ignored whether it is not found in savu sea MNP

- Some students said that species of seal are not found in Savu Sea MNP.

- Some students who have misunderstanding about empty set and the collection of undefined objects said that collection of seal species is not a set since the collection do not have any member.

- Their experience guided them to find the definition of set and an empty set

- Students read the context and Represent the mammal species, whales species, dolphins species, and seal in certain set namely $\mathrm{S}, \mathrm{A}, \mathrm{B}$, and $\mathrm{C}$.

- Students read the context comprehensive and investigate the elements of S, A, B, and C to examine whether they have relation or not, and what kind of relation they have.

- Student represent the set relation (subset, disjoint, equal and equivalent) into venn's diagram.
- Students represent the set in Descriptive form, Set-builder form and Roster form or Tabular form.

- Student invent relation among sets i.e. A and S, $\mathrm{A}$ and $\mathrm{B}, \mathrm{B}$ and $\mathrm{C}$

- Students find the relation between; A and S, B and $\mathrm{S}$. They know that no relation between $\mathrm{A}$ and $\mathrm{B}$, but they cannot find the relation of $\mathrm{C}$ as an empty set with the other set.

- Students represent the relation between the sets more easily in venn's diagram,

- Using the venn's diagram, students were guided to invent that an Empty set is the subset of every other set.

Table 3. Learning Trajectory on Set Operation Laws

\begin{tabular}{|c|c|c|}
\hline Mathematics Goal & Activity & Description \\
\hline $\begin{array}{l}\text { Students found laws on } \\
\text { set operation. }\end{array}$ & $\begin{array}{l}\text { - Students Read the provided context about Species of } \\
\text { Sea turtles found in Savu Sea MNP } \\
\text { - Students list the All species of Sea Turtles found in } \\
\text { Savu Sea MNP as Universal Set Namely S, } \\
\text { - Students list the the members of sea turtle species } \\
\text { found in several regency around the region of savu } \\
\text { sea MNP, such as Kupang, Sumba, Manggarai, TTS, } \\
\text { SabuRaijua, RotenNdao, and Lembata, as some set } \\
\text { which namely respective D, E, F, G, H, I, J } \\
\text { - Students operate combined sets and examinee the } \\
\text { properties of set operation. }\end{array}$ & $\begin{array}{l}\text { - Students represent set in roster } \\
\text { or tabular form } \\
\text { - Students list the members of set } \\
\text { operation (Union, Intersection, } \\
\text { set difference, complement, and } \\
\text { disjoint sets). } \\
\text { - Students find the properties of } \\
\text { sets when they are combined } \\
\text { together such as, Identity laws, } \\
\text { Commutative laws, De } \\
\text { Morgan's, Domination, } \\
\text { Associative, Idempotent, and } \\
\text { Distributive laws. }\end{array}$ \\
\hline
\end{tabular}




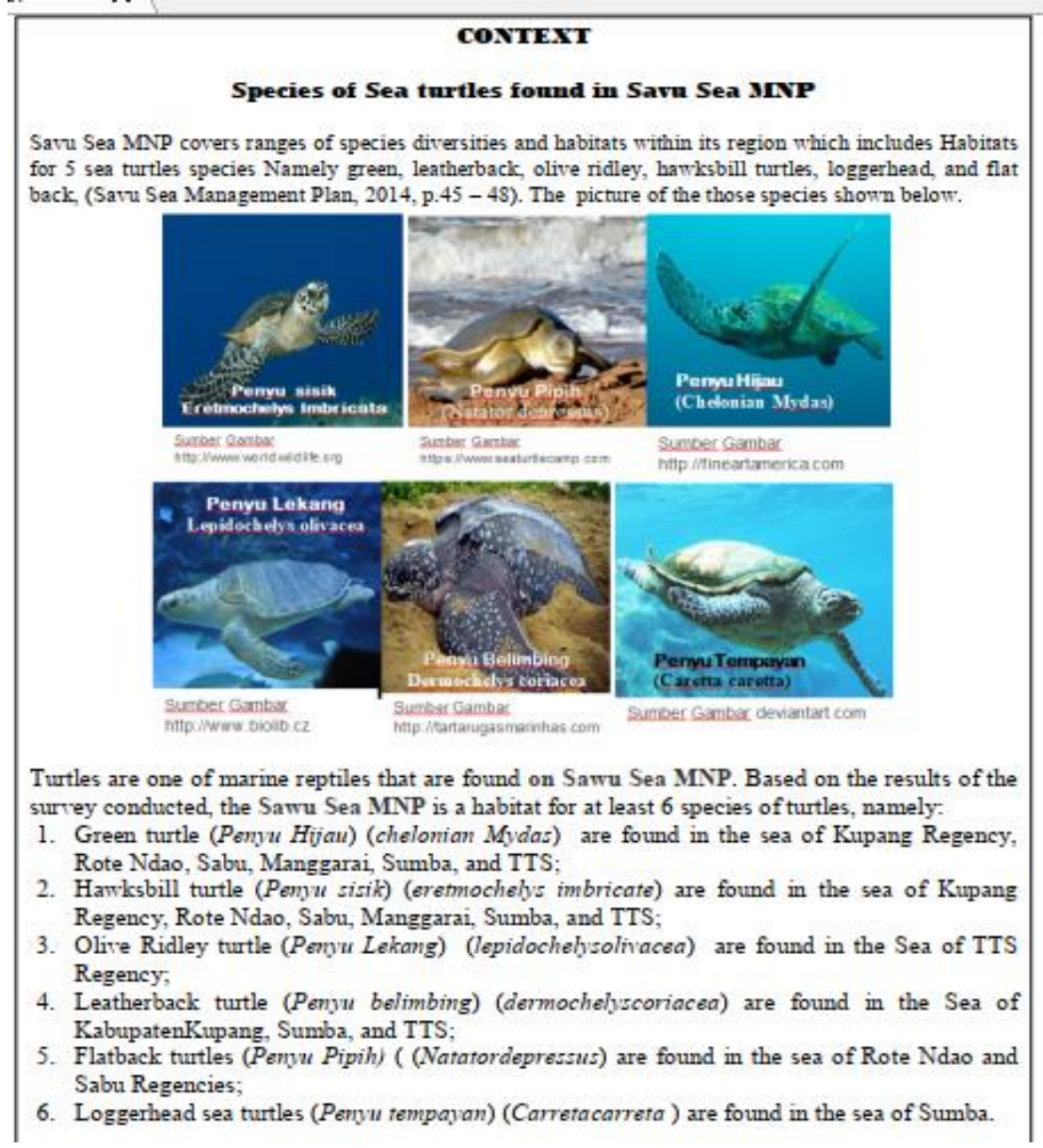

Figure 3. Context about Species of Sea Turtles Found in Savu Sea MNP

\section{Teaching Experiment}

All teaching material had been revised during the pilot experiment stage based on the input from experts, students, model lecturer, observer's field note, and analysis of teaching and learning process from videotaping and students writing. In the pilot experiment, students had difficulties inlisting the names of marine mammals' species; they took long time to write the names of whale, dolphin, and dugongs. They also spent more time and needed an ample space of paper to present sets in Venn diagrams. Thus, the names of some marine mammal species were shortly written in the teaching experiment. Further, the turtles' image was not appropriate with their species; some instruction in students' worksheets need to be revised.

The teaching experiment was conducted in a real class consisting of 32 students. At the beginning of the lesson, students in groups were given text about the context. After reading it, they were given the chance to solve the initial problem before learning set theory more deeply. They had learned about set theory when studying at junior high school. They answered the initial problem based on the information on the context, as shown in Figure 4.

Students' reasons show their unclear understanding of the definition of set. They give the same answer to friends during presentation. They cannot explain it clearly, repeat the question and focus on the existence of set elements.

Students hesitate their answer and did not feel sure if the collection of seals species in the MNP is a set or not. They only answered "It does not have any member element". Some of them did not know about dugong, so they guess that dugong is one of the seal species. In the presentation, they explained that the collection of seals species in the MNP is not a set because it does not have an element (Figure 5).

They gave the same answer to the 3rd and 4th questions without understanding that clever marine mammal species were undefined so they gave different elements of its collection. In the interview, they explained there are no seal species in the MNP, so the seal spe- 
Initial Problems

Instruction!

Read the text about marine mammals in the context. In this worksheet, the marine mammal species are brief as follows;

Whale species are brief as

Dolphinsspecies are brief as : Sw, Dsw, Psw, Sfpw, Orca, fkw, Pkw, Mhw, Beaked w, Cbw, Bw, Pbw, Blue W, Hw.

Dugong species : Sd, Ptsd, Rtd, Rd, Bd, Fd, Ipbd, :Dugong.

\section{Students original works in Bahasa}

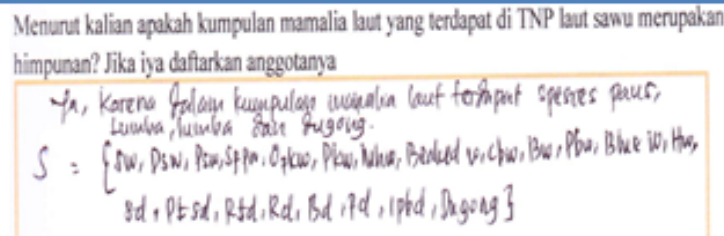

Menurut kalian apakah kumpulan Paus yang terdapat di TNP laut swwu merupakar himpunan? Daftarkan Anggotanya

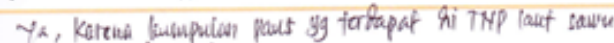
inzimpalcan luscounas.

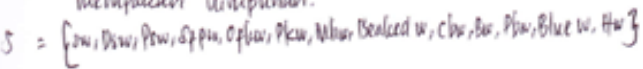

\section{Students' works in English}

\section{Question 1}

Is the collection of marine mammals' species founding in

Savu Sea MNP a set? Explain your answer.

Students Answer

Yes, because of mammals species consist of whales species, dolphins species, and dugong species Sw, Dsw, Psw, Sfpw, 0, fkw, Pkw, Mhw, Beaked w, $S=\{\quad$ Cbw, Bw, Pbw, Blue W, Hw, Sd, Ptsd, Rtd, Rd, Bd, Fd, Ipbd, dugong

\section{Question 2}

Is the collection of Whales founding Sayusea MNP a Set? Ex plain your answer.

Students Answer

Yes, since the group of whales speciesin Sayusea NMCA is a set

$$
S=\left\{\begin{array}{c}
\text { Sw, Dsw, Psw, Sfpw, O, fkw, Pkw, Mhw, Beaked w, } \\
\text { Cbw, Bw, Pbw, Blue W, Hw, }
\end{array}\right\}
$$

Figure 4. The Initial Problems Based on the Information on the Context

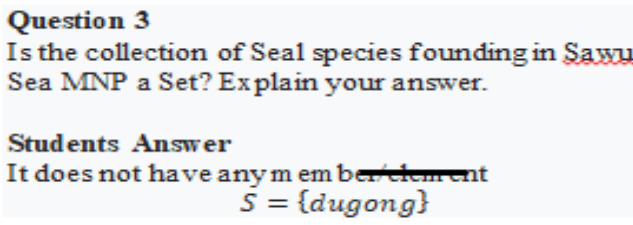

\section{Question 4}

Is the group of clever marine mammals species

founding in Savu MNP a Set? List the members

Students Answer

The collection does not has any member

$$
S=\{\vdots
$$

Figure 5. Students' Response of Confusion and Hesitation

cies collection is a set with no member. Their answers implied that they cannot distinguish the concept of set, collection that is not set, and empty set. They miss the concept of a set as a collection of well-defined objects. It means that collection of undefined objects is not a set.

They also miss the concept of an empty set as a set having no elements. The teacher then guides them to reinvent the concept of set based on the contradictory answer. The lesson was then continued to the next learning out- comes using the second context, distribution of sea turtle in Savu Sea MNP.

Students' answers of questions 1 and (Figure 6) show they understood all the instructions and questions on the worksheet. They answer correctly while four of 35 students gave some false answer because (1) two students not concerned in listing elements of set, (2) three students found it difficult to operate some set with complement of set, (3) two students found it difficult to operate combined set. 
Instruction!

Found the solution of the problems given in worksheet based on information in the

text about the Distribution of Marine Biota, especially "Sea Turtles" found in the

Sawu Sea MNP

If $\mathrm{S}$ is a Set of sea turtles found in the Sawu Sea National Park

$D$ Is a set of sea Turtle found in Kupang Regency

E Is a set of Turtle found in Sumba Regency.

F Is a set of Turtle found in Manggarai Regency.

G It is a set of Turtle found in TTS Regency.

H Is a set of Turtle found in SabuRaijua Regency,

I Is a set of Turtle found RoteNdao regency

I is a Set of Turtles found in Lembata Regency

\section{Question 1}

1. List the members of S, D, E, F, G, H, I, J

Students' answers

$$
\begin{aligned}
& S=\{515 i k \text {, belimbring. Pish, hijaw. Lekang, Tempayan }\} \\
& D=\{\text { sistk, betiontring } P \text {. hy gaw }\} \text {. }
\end{aligned}
$$

$\mathbf{G}=\{$ hijaw , sisik, lekang, belimbring $\}$.

$H=\{$ hejaw, sisik, proith $\}$.

$I=\{$ hiju. Sirik, pipst $\}$.

$J=\{\}$.

Question 2

Operate the set, then find their relation with another set.

Students' Answer

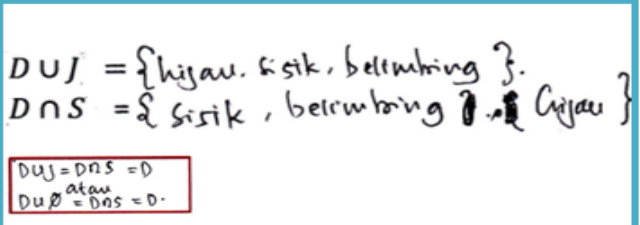

$D \cap D^{c}=\varnothing$

$D \cup D^{c}=\{$ Surk, bettumbring, hagau, Piprh, Lekang, Tempayan $\}$.

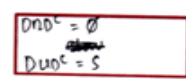

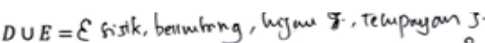

$E \cup D=\{$ hian, sisik, beliming, temparyan $\}$

$D U E=E U D$

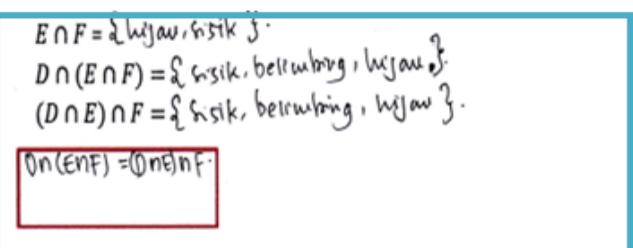

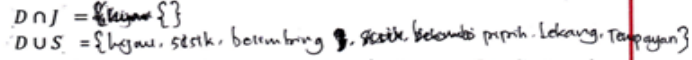

Dnj $=\{3$
on $\ddot{\theta}=\varnothing$

$D \cap E=\{$ sisik, beliutring, hyan $\}$.

$E \cap D=\{$ hilaw, sisik, belsurtrng $\}$

DNE =EnD.
$E \cup F=\{$ Liraw, siske, belimhrug. Tempayan : J

$D \cup(E \cup F)=\{$ Sistk, betembing. hijou, Telupayan $\}$.

$(D \cup E) \cup F=\{$ sisik, belimhing, hyou, tempuyan. $\}$

$\left.D \cup(E U F)=C U_{E}\right) F_{F}$

$D \cup F=\{$ ssik, betimbing. hyou, $\}$

$D \cup(E \cap F)=\{$ sisik, bekmiring, hyan $\}$.

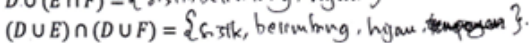

DU (EnF) $=$ (DUE) $n$

(DUF).

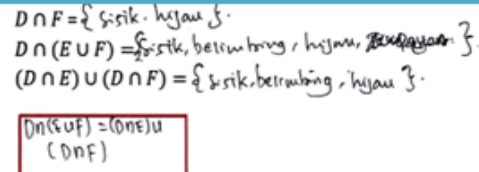

Figure 6. Students' Answers on the Worksheet 


\section{Students' Responses to RME Approach}

At the end of the lesson, the students were asked to respond to the implementation of the realistic mathematics education (RME) approach in their class. They were asked to ex-

\section{Indonesia}

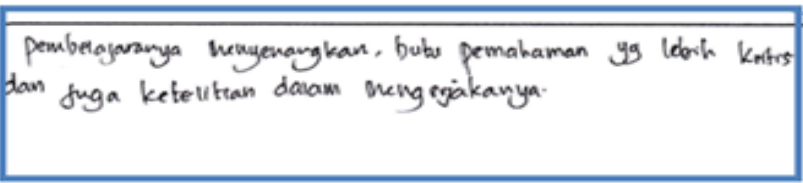

Indonesia

pembelajaranya henyenangkan, bubs permahaman yg lebih kntrs dan juga ketelitian dalam mengerjakanya. press their opinions freely on the implementtation of that learning approach. Their answers, both in Bahasa Indonesia and Engsih, are clearly presented in Figure 7.

\section{English}

The learning process was interesting; It requires critical thinking and accuracy reading tosolve the problem on the worksheet

\section{English}

The learning process was interesting; It requires critical thinking and accuracy reading tosolve the problem on the worksheet

This context is meaningful because it is not only related to mathematics but also about fisheries and marine

lidak hanya tertuju. pada konteks matematika soj

tapi iniberhubungan dengan perigaman dan kebutun

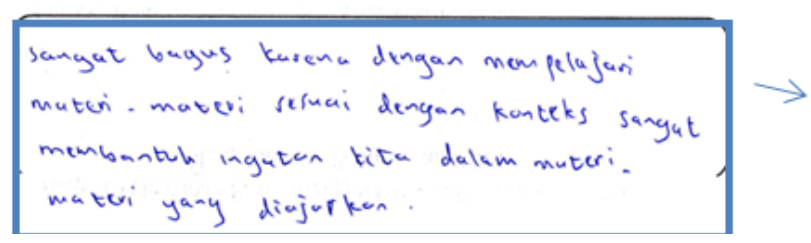

Very good, because studying the material using relevant context is very helpful for us to memorize the subject.

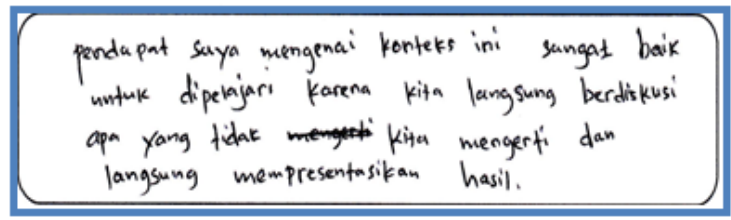

In my opinion, the context is very good Moreover, we can discuss about material that we don't understand and present the results immediately

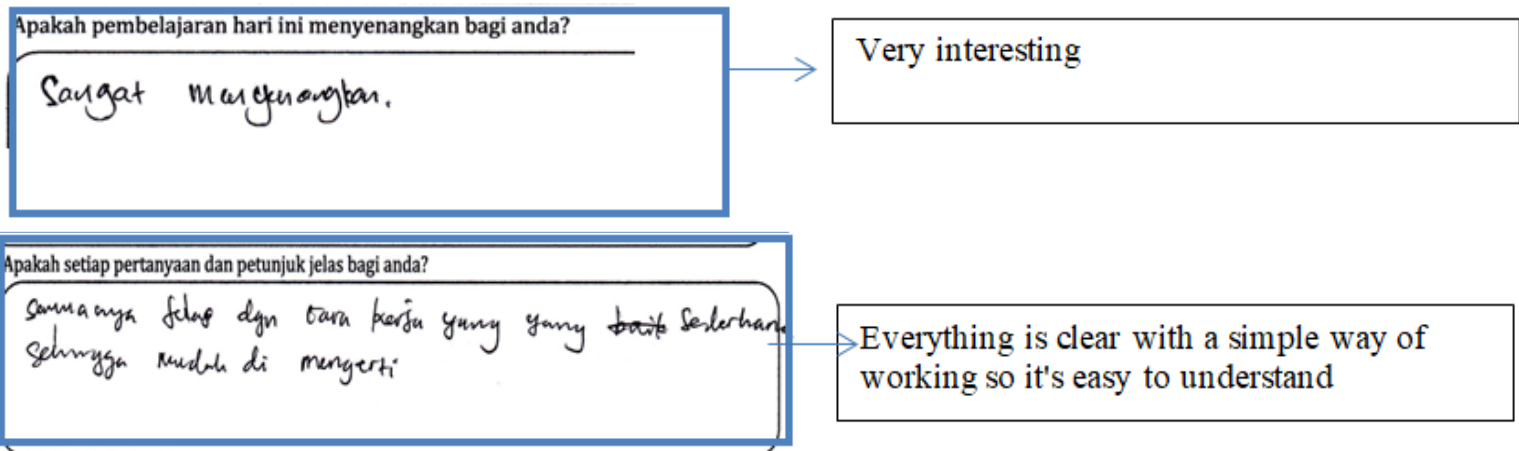

Figure 7. Students' Responses to the Implementation of RME Approach 


\section{Retrospective Analysis}

The retrospective analysis of data collected from both the pilot experiment and the teaching experiment activities are then described. The result of this research is not a design that works but the underlying principles explaining how and why this design works. Consequently, the hypothetical learning trajectory served as a guideline in the retrospective analysis to investigate and explain students' acquisition of the basic concepts set and set operation as experience-based activities. Students' answers showed that they understand all of the given materials. All of the students' strategies and misconceptions predicted in HLT happened in the real class. However, $14.28 \%$ of students still gave some false answers because (1) $5.71 \%$ of them did not concern about listing elements of the set, an example of students' work. (2) $8.57 \%$ of students found it dif-ficult to operate some set with the complement of a set, (3) the rest, $5.71 \%$ student found it difficult to operate combined set. Realistic Mathematics Learning with the context of Savu Sea MNP can attract students' attention. They were more enthusiastic and excited to solve the mathematics task of student worksheets. Those contexts were very fun and meaningful for them. They were not only studied mathematics but also learned about fisheries and the marine field. Clear instructions and systematic explanation of teaching material helped them fully understand the concept of set theory and its operation laws. The use of context related to Savu Sea MNP helped them memories the materials for a long time. Presenting problems at the beginning of learning initiated students to think more openly through the discussion process. The opportunity to present their discussion results helped them to find out the truth of their works immediately.

\section{CONCLUSION}

According to student works and responses, mathematics learning trajectory inset and set operation topics using the RME approach with the context of marine mammals and sea turtles in Savu Sea MNP can explore, construct, and improve student understanding and motivation in the learning process. They enjoy the learning process and give a very enthusiastic response. They solve all of the given problems on the worksheet more easily. It means that the applied RME approach using scientific context related to students' major of study can motivate vocational education college students in learning mathematics.

\section{ACKNOWLEDGMENTS}

The researchers would like to express gratitude to the Polytechnics of Agriculture Kupang (Politeknik Pertanian Negeri Kupang), for funding this research and providing the opportunity and facility to conduct this study. Then, we also thank Yusuf Kamlasi as a teacher model and all of the students as the research subject in this research.

\section{REFERENCES}

Blum, W., \& Niss, M. (1989). Mathematical problem solving, modelling, application, and links to other subjects-state: Trends and issues in mathematics instruction. In W. Blum, M. Niss, \& I. Huntley (Eds.), Modelling application and applied problem solving: Teaching mathematics in a real context. Ellis Horwood.

de Lange, J. (1987). Mathematics insight and meaning. Rijksuniversiteit.

de Lange, J. (1996). Using and applying mathematics in education. In A.-J. Bishop, K. Clements, C. Keitel, J. Kilpatrick, \& C. Laborde (Eds.), International handbook of mathematics education (pp. 49-97). Kluwer Academic Publishers.

Edo, S. I. (2016). Jenis kekeliruan akibat menghafal prosedur rutin dalam melakukan operasi penjumlahan dan pengurangan bilangan pecahan. Mosharafa: Jurnal Pendidikan Matematika, 5(3), 223-234.

Edo, S. I., Ilma, R., \& Hartono, Y. (2013). Investigating secondary school students' difficulties in modeling problems PISAmodel level 5 and 6. Journal on Mathematics Education, 4(1), 41-58. https://doi.org/10.22342/jme.4.1.561.41 $-58$

Fauzan, A., Slettenhaar, D., \& Plomp, T. (2002). Traditional mathematics education vs. realistic mathematics education: Hoping for changes. Paper 
Presented at the 3rd International Conference on Mathematics Education and Society (MES).

Freudenthal, H. (1973). Mathematics as an educational task. Reidel.

Gravemeijer, K. P. E. (1994). Developing realistic mathematics education. Freudenthal Institute.

Gravemeijer, K. P. E. (1981). Het gebruik van contexten. Willem Bartjen, 1, 51-56.

Hodgson, T. (1996). Students' ability to visualize set expressions: An initial investigation. Educational Studies in Mathematics, 30(2), 159-178. https:// doi.org/10.1007/BF00302628

Huffard, C. L., Erdman, M. V., \& Gunawan, T. R. P. (Eds.). (2012). Geographic priorities for marine biodiversity conservation in Indonesia. Ministry of Marine Affairs and Fisheries and Marine Protected Areas Governance Program.

Hussin, H. B., Majid, M. B., \& Ab Wahab, R. B. (2018). Relationship of secondary school mathematics achievement with engineering mathematics 2 in polytechnics. Jurnal Konseling Dan Pendidikan, 6(3), 160-169. https:// doi.org/10.29210/128300

Javed, S. H. (2008). Online facilitated mathematics learning in vocational education: A design-based study. Doctoral thesis. Victoria University, Victoria.

Math-Only-Math.com. (n.d.). Basic concepts of sets. https://www.math-only-math. com/basic-concepts-of-sets.html

Prahmana, R. C. I., Zulkardi, Z., \& Hartono, Y. (2012). Learning multiplication using Indonesian traditional game in third grade. Journal on Mathematics Education, 3(2), 115-132. https://doi. org/10.22342/jme.3.2.1931.115-132

Rusmar, I. (2017). Teaching mathematics in technical vocational education (TVET). Proceedings of the 1st International Conference on Innovative Pedagogy (ICIP).
Simon, M. A. (1995). Reconstructing mathematics pedagogy from a constructivist perspective. Journal for Research in Mathematics Education, 26(2), 114145. https://doi.org/ 10.2307/749205

Treffers, A. (1987). Three dimensions: A model of goal and theory description in mathematics instruction - the Wiskobas project. Reidel Publishing.

van der Kooij, H. (2011). Mathematics for technical and vocational education. Freudenthal Institute.

van der Kooij, H., \& Strasser, R. (2004). TSG 7: Mathematics education in and for work. Denmark 2004 , Denmark: IMFUFA, Department of Science, Systems and Models. In M. Niss \& E. Emborg (Eds.), Proceedings of the 10th International Congress on Mathematical Education (pp. 319-322). IMFUFA, Department of Science, Systems and Models at Roskilde University. http://higeom.math.msu.su/ asmish/Lichnaja-2010/Version2010-1 1-20/Trudy/Publications/2004/icme_ completebook.pdf

Wijaya, A. (2008). Design research in mathematics education: Indonesian traditional games as means to support second graders' learning of linear measurement. Master thesis. Utrecht University, Utrecht.

Zhang, Y. (2014). A research on applied teaching of mathematics at higher vocational colleges. Proceedings of the $3 r d$ International Conference on Science and Social Research. https://doi.org/ 10.2991/icssr-14.2014.264

Zulkardi, Z. (2002a). Developing a learning environment on realistic mathematics education for Indonesian student teachers. Doctoral thesis. University of Twente, Enschede.

Zulkardi, Z. (2002b). Developing a "rich" learning environment on RME for student teachers in Indonesia. Paper Presented in the IAMS-1 Seminar at the Faculty of Mathematics. 